\title{
educational deontology in the community of philosophical inquiry
}

\author{
silvia demozzi ${ }^{1}$ \\ university of bologna, italy \\ orcid id: http:/ / orcid.org/0000-0002-5617-7273 \\ marta ilardo ${ }^{2}$ \\ university of bologna, italy \\ orcid id: https:/ / orcid.org/0000-0002-9413-4549
}

\section{abstract}

This paper aims at offering a pedagogical perspective as part of the debate on philosophical practice with children, referring particularly to issues of educational deontology that emerging "uncomfortable" questions occur. Many of the questions that arise during philosophy sessions - and sometimes individually, at the end of the session and "out of the community borders")--are left unanswered, being perceived as uncomfortable. Our reflection is on what educational deontology requires in order to deal with the challenge that these kinds of questions bring. Starting from the concept of deontology proposed by the educationalist Mariagrazia Contini and embracing Jana Mohr Lone's idea of children's comfort with uncertainty, the paper offers a discussion on what we mean by educational responsibility when undertaking the task of facilitating a community of philosophical inquiry with children. The paper concludes that the facilitator should be present, attentive, and capable of good listening. She/he should be a model, an example for the community: available to listen and answer back, respectful, sensitive, capable of mind shifts, and humble. Moreover, a facilitator should be trained in a reflexive thinking: she/he needs to be well aware of her/his own cognitive schemes, the premises of her/his knowledge, and the social and cultural paradigms she/he refers to. All this "intangibile background" needs to be made explicit in order to be aware of the frames that shape each educational action.

keywords: children; community of philosophical inquiry; educational deontology; responsibility.

\section{deontología educativa en la comunidad de investigación filosófica.}

resumen

Ese texto tiene como objetivo ofrecer una perspectiva pedagógica como parte del debate sobre las prácticas filosóficas con niños, refiriéndose particularmente a los asuntos de deontología educativa que surgen cuando ocurren preguntas "incómodas" (pero no solo). Muchas de las preguntas que surgen durante las sesiones filosóficas (o, a veces, individualmente, al final de la sesión y "fuera de la frontera comunitaria") quedan sin respuesta, siendo percibidas como incómodas. Nuestra reflexión es sobre lo que requiere la deontología educativa para enfrentar el desafío que conlleva este tipo de preguntas. Partiendo del concepto de deontología propuesto por la pedagoga Mariagrazia Contini y abrazando la idea de Jana Mohr

\footnotetext{
${ }^{1}$ E-mail: silvia.demozzi@unibo.it

2 E-mail: marta.ilardo@unibo.it
} 
educational deontology in the community of philosophical inquiry

Lone de la comodidad de los niños con la incertidumbre, el documento ofrece una discusión sobre lo que entendemos por responsabilidad educativa al emprender la tarea de facilitar una comunidad de investigación filosófica con niños. El texto concluye que el facilitador debe estar presente, atento, capaz de escuchar bien. Ella/él debe ser un modelo, un buen ejemplo para la comunidad: disponible para escuchar y responder, respetuoso, sensible, capaz de cambios mentales y humilde. Además, un facilitador debe estar capacitado para un pensamiento reflexivo: debe ser consciente de sus esquemas cognitivos, las premisas de su conocimiento, los paradigmas sociales y culturales a los que se refiere. Todo este "fondo intangible" debe hacerse explícito para conocer los marcos que dan forma a cada acción educativa.

palabras clave: niños; comunidad de investigación filosófica; deontología educativa; responsabilidad.

\section{deontologia educacional na comunidade de investigação filosófica}

resumo

O artigo tem como objetivo oferecer uma perspectiva pedagógica como parte do debate sobre práticas filosóficas com crianças, referindo-se particularmente a questões de deontologia educacional que surgem quando ocorrem perguntas "desconfortáveis" (mas não apenas). Muitas das perguntas que surgem durante as sessões filosóficas (ou às vezes individualmente, no final da sessão e "fora da fronteira da comunidade") são deixadas sem resposta, sendo percebidas como desconfortáveis. Nossa reflexão é sobre o que a deontologia educacional exige para lidar com o desafio que esse tipo de questão traz. Partindo do conceito de deontologia proposto pela pedagoga Mariagrazia Contini e adotando a ideia de Jana Mohr Lone de conforto das crianças com a incerteza, o artigo oferece uma discussão sobre o que entendemos por responsabilidade educacional ao assumir a tarefa de facilitar uma comunidade de investigação filosófica com crianças. $\mathrm{O}$ artigo conclui que o facilitador deve estar presente, atento, capaz de ouvir bem. Ela/ele deve ser um modelo, um bom exemplo para a comunidade: disponível para ouvir e responder, respeitoso, sensível, capaz de mudar de ideia e humilde. Além disso, um facilitador deve ser treinado para um pensamento flexibilizado: ele/ela precisa estar bem ciente de seus esquemas cognitivos, das premissas de seu conhecimento, dos paradigmas sociais e culturais a que se refere. Todo esse "plano de fundo tangível" precisa ser explicitado para estar ciente dos quadros que moldam cada ação educativa.

palavras-chave: crianças; comunidade de investigação filosófica; deontologia educacional; responsabilidade. 
educational deontology in the community of philosophical inquiry

\section{1. introduction: "uncomfortable questions" and educational deontology}

The paper aims at offering a pedagogical perspective as part of the debate on philosophical practices with children, referring particularly to educational deontology matters emerging when "uncomfortable" questions (but not only) occur.

The philosophical practice is largely recognized to be valuable for education. Philosophical practice with children starts from Lipman's thinking, that the philosopher himself used with his students ${ }^{3}$; so, we can say that philosophical practice with children has been having an educational significance from its very origins (Lipman, Sharp, Oscanyan 1977; Lipman 1991; Lipman 2008).

Previous studies (Gregory, Haynes, Murris, eds. 2016; Gregory, Laverty, eds. 2019) have highlighted both the value of this method in terms of critical, caring, creative, and cosmopolitan thinking and the degree to which it supports the building a community of inquiry. Such a community is also a space for individual and collective emancipation and growth. Starting from these findings, we would like to add our reflection about educational deontology.

During our own experience ${ }^{4}$ within philosophical communities of inquiry, formed by children between 6- and 14-years attending school of Bologna (Italy), an event has often showed. This had been questioning our educational responsibility. Here we are referring to a moment that arises between the questions of children of girls and boys - and the answers they provide either on their own or with the help of the facilitator, depending on the method the facilitator is employing. Many of the questions which emerge during sessions of philosophical practice (or some-

\footnotetext{
${ }^{3}$ Lipman was persuaded that learning to think critically, to inquire about philosophical questions and to form reasonable judgments should begin much earlier in life than at University. See Lipman's autobiography, A Life Teaching Thinking (2008).

${ }^{4}$ Our activity with Philosophy for/with Children started at the beginning of 2017, within a research group, named Farfilò, at the University of Bologna. Farfilò has been a research group on philosophical practices with children, founded and coordinated by Author1 and Sebastiano Moruzzi, researchers at the Department of Education and at the Department of Philosophy and Communication. The group worked on these practices from both a methodological and theoretical perspective, organized seminars and workshops on the philosophical and pedagogical foundations of philosophical practices with children and created opportunities for students and young researchers to practice philosophy with children. For more information: https://site.unibo.it/farfilo/it.
} 
educational deontology in the community of philosophical inquiry

times individually, at the end of a session and "out of the community borders") are left unanswered, being perceived as uncomfortable. In order to understand the role of the facilitator, we want to reflect on what educational deontology requires in order to deal with the challenge that these kinds of questions bring along. Our role as educational researchers and educators is questioned about the educational responsibility we have towards the members of the community of inquiry.

To clarify our point, we assume as "uncomfortable questions" those that Chetty and Suissa (2017) define as questions that bring along a sort of discomfort in the facilitator and in the community. Their analysis focuses on racial issues, but we can broaden the definition also to more existential questions that deal with the deep matter of life: questions about life and death, the existence of God, good and evil, the origin of life, for example. Or, more generally, we might focuses on questions "that can sweeping in scope and grandeur"(Kizel, 2016, 3).

We will report an actual episode to establish better. Asked by the facilitator to write down his favourite question, Luca5, 11 years old, writes: "Why am I the devil? Why can't I control myself?". Surely, this is a philosophical question6. But it may also be an "uncomfortable" one, since it opens up to an existential issue for the individual and, perhaps, for the whole community. From our point of view, this is actually a question that brings along much food for thought if it appears in an educational context. Why does Luca think of himself as a devil? In which context? Does he think that everywhere, or just at home? Or just at school? What does Luca doesn't manage to control? Thoughts? Emotions? Movements? In relation to whom cannot he control himself? Perhaps in relation to his parents, or to adults in general? In relation to his peers?

The philosophical practice inevitably includes questions like Luca's one. These questions are related to the problem of one's identity, of the others' look upon us, of the conflict between rationally-oriented will and much less controllable tensions in one's personality. In these cases, researches are asked to reflect on

\footnotetext{
${ }^{5}$ Luca is a fictional name.

${ }^{6}$ It raises the problem of Akrasia or weakness of will.
} 
the meaning of being human. Hence, a pedagogical and deontological "sensitivity" is required.

We ask ourselves how a facilitator can participate in the conversation opened up by Luca's question, even if it brings along discomfort and, maybe, silence. Which should be her/his educational deontology in order to respect Luca? What kind of thinking could spread so that is somehow productive for the community, but at the same time in a way that is "sensitive" to the individual, guaranteeing the compliance with a certain kind of educational aim?

In the following paragraphs we will try to give an answer to these questions. In $\S 2$ we will offer an overview of what we mean by the concept of educational deontology7 deriving it from Mariagrazia Contini's proposal. In $\S 3$ we will underline what kind of "effort" we assume could be shown if both the facilitator and the community are able to "stay in the conversation" even when discomfort rises, considering Jana Mohr Lone idea that children show more comfort than adults with uncertainty. In $\S 4$ we will try to show how we envision asymmetry and responsibility as significant principles to undertake the challenge of facilitating with respect to deontology. In $\$ 5$ we will refer to the "struggle" related to the practice of thinking together and to the educational relevance of taking care of it. In $\S 6$ we will conclude offering a pedagogical perspective.

\section{2. educational deontology}

What we address with the concept of pedagogical deontology derives from the thinking of Mariagrazia Contini (2014) and her philosophy of education, known in Italy under the name of "problematicismo pedagogico" (Bertin, Contini, 2004). This educational perspective doesn't offer any solution in terms of "educational recipes", but rather deals with some ethical principles each person with an educational responsibility should comply with. The pedagogical deontology, actually, doesn't try - or not just - to reply to the question: "What has to be done?", but rather defines an ideal regulation within which each educational action should be framed ("What rules am I expected to conform to?").

\footnotetext{
${ }^{7}$ Deontology is the set of moral rules governing the exercise of a given profession.
} 
educational deontology in the community of philosophical inquiry

The reason why such a reflection about deontology emerges is motivated by the absence of a "code" in the educational field (that is instead present in other professions, e.g. physicians or lawyers, whose deontological duties are well enshrined in a code of regulations), that should guarantee the benefit of any educational action.

Mariagrazia Contini identifies a set of moral norms8 able to steer a "responsible" educational action. The challenge is here represented by the attempt to find the boundaries of legitimation and recognition of moral behavior within which to inscribe any educational action. With regard to this intention, it seems important that each educational action has the opportunity to confront and regenerate with a sort of code of conduct. Therefore, deontology, represents the ethical declination of an educational professional role, guaranteeing and protecting individuals whom educational actions are addressed to.

Based on this definition, which principles - wide enough to embrace any kind of difference (social, cultural, historical - are to be defined?

Mariagrazia Contini proposes 3 principles to comply with, summarized as follows.

First of all, educators shouldn't harm; it may seem trivial but this reminds of the importance, for who is entitled with educational responsibility, to be well aware about the power within their own position. This recalls the concept of authority in education that swings - quoting the reflection of Michaud and Välitalo (2017) - from a traditional and severe authority model (totally teacher-centered) to an anarchist model $^{9}$.

\footnotetext{
${ }^{8}$ Norms that guide the practical behaviour, as they are here intended to indicate what the good is, what the means to achieve it are and what the moral duties towards oneself and others in an educational context are.

${ }^{9}$ Michaud and Välitalo (2017) systematize the debate on authority in education by identifying three dominant positions: 1) the traditional model, 2) the anarchist model and 3) the shared authority model. The first position favours a model of transmission of knowledge that has been endorsed by a tradition. The second position is based on the idea that there should be no exercise of authority in education. The last model, to which we refer here, recalls the thought of Dewey (1938), who invites us to consider the positive aspects of both previous models, eliminating their negative features (e.g. repression or unconditional freedom). In fact, the teacher has a role as an authoritative figure in the classroom, but at the same time, education should always start from the students' interests. Students and teachers are therefore committed together to co-constructing authority.
} 
What these authors try to define is a third model, that we think is linked to the first principle proposed by Contini: the "shared authority" model. The educator, actually, plays a role with a high responsibility towards her/his students - in order to not harm them, she/he is asked to respect their subjectivity, considering their interests and talents with an inclusive perspective. Contini suggests to always side with non-violent forms of actions and communication. This means, to make an example, having the ability to live within conflicts in a constructive way, avoiding humiliation and oppression of the other.

The second principle states: "make room for everyone, no one left behind"; this means, to a certain extent, that each student should be supported in the discovery of her/his horizon of possibilities. Education should promote - no one left behind- an existential project (Bertin, 1995) focused on going beyond each Verfallenheit (befallen) (Heidegger, 1927), trying to make room for a plurality of existential possibilities. In other words, each subject has the right to "realize her/his own difference" (Bertin, Contini, 2004), moving from her/his "given condition" (Verfallenheit) to a "chosen one". Through this principle, Contini wants to emphasize the duty of teachers and educators, to support students in overcoming their initial conditioning in order to choose what is really significant to them.

The third and last principle recalls the importance of a "resistant" commitment to the benefit of those who are left behind. In line with a pedagogy of freedom (Freire, 1971), this means taking on responsibility in order to remove (or at least try to) the socio-cultural obstacles that are responsible for certain kind of disadvantages. That matters for all those categories of people who are easily marginalized within a society (e.g. women, children, migrants, homosexual, people with disability...) and who could find themselves marginalized also within a community of inquiry.

Hence, this kind of educational deontology openly strives for a goal: it commits teachers to supporting those students who, among all, start from a disadvantaged position and - as a consequence - encounter much more difficulties in emancipating themselves. 
educational deontology in the community of philosophical inquiry

\section{3. looking from a window with no railing}

In our view, educational deontology is not anyway merely conceived as a range of principles or competences, but also as a way to accompany students along their educational path and to hopefully enable them to emancipate themselves in their existential project. Fostering philosophical practices within an educational community and valuing the importance of thinking within an existential project, seems to us an essential task of the above-mentioned deontology. A sort of "tool" of a deontology like the one mentioned above.

Philosophy with/for children and the community of inquiry actually appear to represent a safe context within which carrying out this kind of deontological principles. At the same time, it also seems to be the context within which - recalling the issue of discomfort - a facilitator should be particularly sensitive to those principles. In order to "make room for everyone, no one left behind", a facilitator should learn how to guide a discussion that actually offers a voice to each member of the community and that legitimates even those questions that are difficult to embrace (such as Luca's question).

What kind of thinking is fostered if both the facilitator and the community are able to "stay in the conversation" (also with discomfort)? A thinking which is strongly connected with its "caring" dimension, that is "strongly relational". Embracing discomfort, actually involves an openness that goes beyond one's sure assumption about philosophy (and about existence), and supports the acceptance of a certain kind of perplexity and interruption (Cavell, 1979).

As Walter Kohan points out, this doesn't recall philosophical thought "as a set of abilities or tools", but rather "an event", "an experience" $(2014,40)$, in which it unexpectedly happens that the facilitator, or the child, or the whole community is struck and stuck. This kind of experience (or kind of thinking) requires what we have defined as an educational deontology or, in other words, an attentive pedagogical listening.

Existential questions bringing along a certain amount of discomfort arise more than expected in the community of philosophical of inquiry, probably because, as Jana Mohr Lone states, "during early childhood, most children are wide open 
to the mysteries that pervade human life and are curious about the most basic framework of human experience, including such subjects as the meaning of being alive, the complexity of identity, the nature of friendship and love, how to live good lives, and whether we can know anything at all $(2018,55)$ ". In the "childhood of their time", children possess an "epistemic openness" (Mohr Lone, 2018, 57) which corresponds to a mind freer to imagine things, if compared to adults' one.

We could also say that, what sometimes happens within the community of inquiry is a kind of thinking that make us feel, quoting Arendt's words, as if we were "looking from a window with no railing" (1953-1975). The community offers the possibility to "apply to" such a sense of wonder towards what surprises us as well as towards what horrifies us (causing a sort of struggle and discomfort).

The philosophical practice should be committed to preserving this peculiarity and safeguard it from the cognitive rigidity and conformism that comes along with adulthood. But this means - as Mohr Lone continues - a certain kind of "comfort with uncertainty, with the possibility that we might not have all the answers, and a willingness to change our minds if persuaded to do so" $(2019,57)$.

\section{4. the challenge of educational deontology: asymmetry as a responsible action}

Since we think that the facilitator of philosophical practice has always an educational responsibility ${ }^{10}$, we also assume that she/he should adhere to an educational deontology, as it has been described above. The facilitator is responsible for ensuring the possibility for everyone in the community to find her/his own role whether active or passive ${ }^{11}$ (Murris 2000; Kennedy 2004; Golding 2012).

The space of the community must be safe for each member; everybody should feel free to be in the community, and to decide whether or not to take part

${ }^{10}$ The concept of responsibility is intended here as exercised in the context of interpersonal relationships; the noun derives from the Latin spondeo (I promise, I give my word), and the connection with the word "reply" is evident, as in German Verantwortung where the word Antwort (reply) implies others.

${ }_{11}$ One might here think that "a passive role" is rather a "non-role" within the community of inquiry and, therefore, not too desirable. However, by referring to "passivity" we claim here the right of a subject to participate with her own time, which could also mean remaining "in the background", observing and listening. Deontology, in this case, would require the facilitator to not forget but rather to include the subject who remains "in the background", imagining alternative strategies to transform her/his "passivity" into a more active participation. 
educational deontology in the community of philosophical inquiry

in the inquiry, without perceiving disagreement, discussion, or silence as something violent.

Far from adhering to a severe authority model, the facilitator tries to take care of the "wellbeing" of the community, guiding the group towards the building of a shared authority model. This means that the facilitator is responsible not merely from a philosophical point of view; she/he is also responsible for maintaining an atmosphere that protects the various individualities of the group and the relations within the group. In other words, the facilitator is responsible for the pedagogical value of the community.

In accordance with this point of view, thinking is conceived as an enterprise which is both affective and cognitive, both social, and personal (Splitter, Sharp 1995). An enterprise in which, to quote Gregory, philosophy is practiced along with "self-examination, a certain ethics of dialogue, communal caring, and a focus on how to live" $(2011,201)$. Recalling another writing of the same author, we can also say that, in order to undertake such a kind of enterprise, the facilitator has to be "pedagogically strong" (Gregory, 2008).

Aiming at being "pedagogically strong", adults should preserve asymmetry: but not in terms of epistemic knowledge (every thought should receive the same right to be listened). All the questions raised by children should have the same dignity as those raised by adults. Otherwise, as Mohr Lone relates, "an epistemic injustice towards the children" would take place (2018, p.61).

Asymmetry should be performed by guaranteeing that the inquiry is taking place in a safe educational space, "within which students (young or old) can begin to ask fertile questions about themselves, their lives, their environment, and above all the changing world they discover via their as-yet unfettered originality that is still free from the search for perfection" (Kizel, 2016, 4). It is a space where adult members keep in mind the above-mentioned deontological principles and ensure a nonviolent attitude (and a responsible action) within it.

We refer to a responsible sensitivity that the adult has with respect to the context and the process, not to a hierarchical organization of ideas, of questions and of answers brought up in inquiry. The "power" of asymmetry we refer to has 
nothing to do with the exercise of authority (in its traditional meaning); it is closely related to the educational responsibility to put the other in the condition of exercising her/his powers in terms of complex thinking, as Lipman described it.

One could also understand this "asymmetry" as the duty of taking on a role that is not "neutral" from an educational point of view, which implies making choices, exercising reflexivity, siding with those subjects who are vulnerable or marginalized.

This concept of deontology offers an idea of education not merely conceived as a way to provide a series of (hard or soft) skills, but also as a way to support individuals in gaining tools that enable them to emancipate themselves in order to accomplish their existential project. Therefore, the exercise of thought is strongly relational to this extent. This project is never unrelated with the relation one has with others and, because of this, it can only be brought about in the relationship with others. Therefore, the exercise of thought is strongly relational to this extent.

In such a space, the arguments in discussion shouldn't be experienced as "arguments from authority", but rather as opportunities ${ }^{12}$. Moreover, the space of such a community, as Sharp puts it, "engender[s] care for one another as persons with rights, a tolerance for each other's views, feelings, imaginings, creations as well as a care for one another's happiness equal to the concern one has for one's own happiness" (1987, $37)$.

\section{5. the "burden" of thinking together and the importance of taking care of this spa-} ce

This kind of deontology safeguards the pursuit of a kind of thinking that, beyond its engagement in the inquiry, tries to open to pluralism, and displays an ethical thelos. In the frame of this purpose, problems never affect just the single in-

\footnotetext{
${ }^{12}$ Concerning this issue, it is interesting to refer to Richard Rorty's thought when he argues that many of philosophy's traditional concerns are redundant, and that the goal of inquiry should not be truth but human betterment. We think that socialization - such as being able to live with others and perceive their diversity as a value - has also to do with human betterment: Rorty believed that the role of philosophy is to conduct an intellectual "conversation" between contrasting but equally valid forms of intellectual inquiry, with the aim of achieving mutual understanding and resolving conflicts (Rorty 1989).
} 
educational deontology in the community of philosophical inquiry

dividual, but the community as a whole and, as such, can never be solved by the individual, but only by the community. Therefore, we argue that the interaction of education and philosophy is authentically realized only on one condition: it's either a matter of community, or it's not at all.

To make this happen, in addition to the competences that Dewey considers to be useful to educate a "democratic citizen", we identify the facilitator's struggle to deal with existential questions or, as we called before, "uncomfortable" ones. Questions that often raise within a community along with the sense of wonder, but also with anguish or discomfort. According to this meaning, Luca's question is problematic and taking care of it also means taking care of his well-being and the well-being of the other participants.

How can we step into "the no go zone" (Chetty and Suissa, 2017) and, to relate to the metaphor of Hannah Arendt, support the members of the community to hang out their windows with no railings? If this isn't possible in a protected environment such as the community of inquiry, where is it then? If education doesn't take care of this, who will then? In other words, if we, as adults, do not take the responsibility to accompany the members of the community towards this experience, where has the above-mentioned commitment to educational deontology gone to, then?

According to Nancy Vansieleghem,

[...] the challenge for education is to create a space where children can encounter the other and where they can start the quest to find out what this encounter means. A space where the collective search for the question 'What happens to me, why does it happen, and what do I have to do with it?' can start. The answer to this question is not a matter of getting to know myself better or of building my own identity but of looking at my life as if I had not seen it before and of changing it. It is about looking for an answer to something that has confused me and where I, together with others, try to respond [...] $(2005,29)$.

The exercise of thought cannot just consist of "reflexive problem solving", as a competence to learn, but also of a "genuine" experience, which can upset and embarrass the subject, fluster her/him, call her/him into question, and perplex her/him. This is what Socrates exemplifies by the use of the metaphor of the wind (Xenophon), an invisible entity whose effects are however concrete and visible. As 
Arendt argues, "If the wind of thinking [...], has shaken you from your sleep and made you full awake and alive, then you will see that you have nothing in your grasp but perplexities, and the best we can do with them is to share them with each other" $(1978,174-$ 175).

In line with this reflection, we acknowledge how important it to preserve this "wind of thinking". The facilitator should be able to set a space that values this dimension and to protect the community members from the world as it is, and from its attempts to "contaminate" their uniqueness (newness). As Biesta claims, "uniqueness, is precisely about the way in which each individual is not a specimen of a more general definition of what it means to be human" (2011, 314), so something 'uniquely new' (Arendt, 1958).

How is a space that allows every individual to express their "wind of thinking" settled? A space in which "uncomfortable" questions could also emerge, and not just questions about how knowledge is built? A space where one doesn't necessarily get to a dialogical synthesis or to an absolute truth, but manages to face the possibility that there is no synthesis, and deals with the anguish that derives from it. How we could define the space that often materializes between questions and answers, that asks to stay in the "conversation"? Going back once again to Arendt, we can portray this space as "in-between" (Arendt, 1958). As the word itself suggests, this space is a dialogical but unforeseeable and unexpected intersection, a space that cannot even be thought without the interlocutors.

\section{6. conclusion}

To conclude, how could a facilitator translate such a deontology into practice within a community of inquiry?

In the first place, the facilitator should be present, attentive, capable of good listening. She/he should be a model, a good example for the community: available to listen and answer back, respectful, sensitive, capable of mind shifts and humble.

Moreover, a facilitator should be trained to a reflexive thinking: she/he needs to be well aware of her/his cognitive schemes, the premises of her/his knowledge, the social and cultural paradigms she/he refers to. All this "intangible 
educational deontology in the community of philosophical inquiry

background" needs to be made explicit in order to be aware of the frames that shape each educational action.

Besides the philosophical competences, the facilitator should take explicitly care of the experience of being among others, of being exposed to them. If this attentive care is clear to the community, each subject could participate, even outside of a "comfort zone" (i.e. in a conversation with discomfort, like the one Luca's question arises). If this premise is clear, then every subject - not just the facilitator - will learn to take responsibility on herself/himself.

This goes along with the deontological principles defined above, considering the fulfilment of one's existential project - being aware of the necessary and irreducible presence of others - as an educational goal. To put the wellbeing of the community among the objectives of the practice could also value the "discomfort" experience, which otherwise may remain just an individual experience, often unresolved, with a burden of unshared anguish.

An educationally-oriented facilitator should be educated also in respect of this objective, aiming at not "loosing" (and therefore "preserving") the precious nature of the questions that are difficult to embrace. This is possible if the adult starts from the assumption that the unknown related to the exercise of thought (which becomes "unforeseen") can take place and should be included within the practice.

A possible way to value this exercise of thought and the construction of this kind of context consists in paying attention to the epistemic openness of childhood. Being originally in-fans, without word, childhood is closer, when compared to adults, to wonder, to discovery, and maybe to the possibility of being without an answer, hanging out the window with no railing, staying "in-between".

To sum up, we believe in the need of acknowledging children and girls and boys not just as subjects who bring questions and sometimes wild issues, but also as subjects who - when approaching existence, next to the moment of inquiry and discovery - will also have to face the moment of suspension and anguish, of senselessness and unknown. 
Taking care of that means not forgetting that it is us - as adults - who draw the frames13 within which children are cared for and within which we assume to promote their emancipation. We are drawing these frames and this cannot be separated, in terms of effects, from us being adult human beings, with a well rooted history on the background.

Children may also be freer than us, but they are living within our "frames". Doesn't this recall our responsibility and a strong educational deontology?

\section{references}

Arendt, Hannah. 1958. The human condition. Chicago: University of Chicago press.

Arendt, Hannah. 2018. Thinking without a banister: essays in understanding, 1953-1975. New York: Schocken.

Banfi, Antonio. 1943. Per un razionalismo critico. Como: Marzorati.

Banfi, Antonio. 1953. La crisi dell'uso dogmatico della ragione. Milano: Bocca.

Bateson, Gregory. 2000 [1972]. Steps to an ecology of mind: collected essays in anthropology, psychiatry, evolution, and epistemology. Chicago, Illinois: University of Chicago Press.

Bertin, Giovanni Maria. 1995. Educazione alla ragione. Lezioni di pedagogia generale. Roma: Armando.

Bertin, Giovanni Maria, Contini, Mariagrazia. 2004. Educazione alla progettualità esistenziale. Roma: Armando editore.

Cavell, Stanley. 1979. The claim of reason: Wittgenstein, skepticism, morality, and tragedy. Oxford: University Press.

Chetty, Darren, Suissa, Judith. 2017. No go areas': Racism and discomfort in the community of inquiry in Maughn Rollins Gregory, Haynes Joanna, Murris Karin, The Routledge International Handbook of Philosophy for Children. London: Routledge, 1118.

Clinton, Golding. 2012. "The Teacher as Guide: A conception of the inquiry teacher". Educational Philosophy and Theory, 45, 1, 91-110.

Contini, Mariagrazia. 2014. L'impegno per una resistenza pedagogica: tra riflessività e deontologia in Contini, Mariagrazia, Demozzi, Silvia, Fabbri, Maurizio, Tolomelli, Alessandro. Deontologia pedagogica. Riflessività e pratiche di resistenza. Milano: Franco Angeli, 13-45.

Dewey, John. 1916. Democracy and Education. An Introduction to the Philosophy of Education. London: Macmillan

Freire, Paolo. 1971. La pedagogia degli oppressi. Milano: Mondadori.

Gregory, Maughn Rollins, Laverty Megan Jane. 2018. In community of inquiry with Ann Margaret Sharp. London: Childhood, philosophy and education, Routledge.

Gregory, Maughn Rollins. 2004. "Practicing democracy: Social intelligence and philosophical practice". International Journal of Applied Philosophy, 18(2), 163-176.

13 The concept of framing was first defined by Gregory Bateson as a "spatial and temporary bounding of set of interactive messages" $(1972,197)$ that operates as a form of metacommunication. 
educational deontology in the community of philosophical inquiry

Gregory, Maughn Rollins. 2007. "Normative dialogue types in philosophy for children". Gifted Education International, 22(2-3), 160-171.

Gregory, Maughn. 2011. "Philosophy for Children and its Critics: A Mendham Dialogue". Journal of Philosophy of Education, Vol. 45 (2): 199-219.

Heidegger, Martin. 2010 (1927). Sein und Zeit. Berlin: Oldenbourg Verlag.

Kennedy, David. 2004. "The role of a facilitator in a community of philosophical inquiry". Metaphilosophy, 35(5), 744-765.

Kizel, A. 2016. "Philosophy with children as an educational platform for self-determined learning". Cogent Education, 3(1), 1244026.

Kohan, Walter. 2014. Philosophy and Childhood: critical perspectives and affirmative practices. US: Palgrave Macmillan.

Lipman, Matthew. 1967. What Happens in Art. New York: Appleton Century Crofts. Lipman, Matthew. 1991. Thinking in education. New York: Cambridge University Press. Lipman, Matthew. 1995. "Moral Education higher-order Thinking and Philosophy for Children". Amsterdam: Early Child Development and Care, vol. 107, pp.61-70, Overseas Publishers Association.

Lipman, Mattwhes 2008. A Life Teaching Thinking. Montclair, NJ: Institute for the Advancement of Philosophy for Children.

Lone, Jana Mohr. 2011. "Questions and the community of philosophical inquiry". Childhood E philosophy. 7(13), 75-89.

Michaud, Olivier, Välitalo, Riku. 2017. Authority, democracy and philosophy: the nature and role of authority in a community of philosophical inquiry in Gregory Maughn Rollins, Haynes Joanna, Murris Karin, The Routledge International Handbook of Philosophy for Children. London: Routledge, 27-33.

Murris, Karin. 2000. "The role of the facilitator in philosophical inquiry". Thinking: The journal of philosophy for children, 15(2), 40-46.

Resnick, Lauren. 1987. Education and Learning to Think. Whashington DC.: National Academy Press.

Rorty, Richard. 1989. Contingency, Irony, and Solidarity. Cambridge: Cambridge University Press.

Sharp, Anne Margareth. 1987. "What is a 'Community of Inquiry'?". Journal of Moral Education, 16(1): 37-45.

Sharp, Ann Margareth. 1991. "The community of inquiry: Education for democracy". Thinking in education, The journal of philosophy for children, 9(2), 31-37.

Splitter, Laurance, \& Sharp, Ann Margareth. 1995. “Teaching for better thinking: the classroom community of inquiry". Australian Council for Educational Research, Ltd., 19 Prospect Hill Rd.

Van Manen, Max. 2016. Pedagogical tact: Knowing what to do when you don't know what to do. Abingdon-on-Thames: Routledge.

Vansieleghem, Nancy. 2005. "Philosophy for children as the wind of thinking". Journal of Philosophy of Education, 39(1): 19-35.

received in: 21.01.2020

accepted in: 03.03.2020 